\title{
Anti-inflammatory and Antinociceptive Activity of Epiisopiloturine, an Imidazole Alkaloid Isolated from Pilocarpus microphyllus
}

\author{
Valdelânia G. Silva, ${ }^{\dagger}$ Renan O. Silva, ${ }^{\dagger}$ Samara R. B. Damasceno, ${ }^{\dagger}$ Nathalia S. Carvalho, ${ }^{\dagger}$
} Rafael S. Prudêncio, ${ }^{\dagger}$ Karoline S. Aragão, ${ }^{\dagger}$ Maria A. Guimarães, ${ }^{\dagger}$ Stefano A. Campos, ${ }^{\dagger}$ Leiz M. C. Véras, ${ }^{\dagger}$ Markus Godejohann, ${ }^{\S}$ José Roberto S. A. Leite, $^{\dagger}$ André L. R. Barbosa, ${ }^{\dagger}$ and Jand-Venes R. Medeiros* ${ }^{* \dagger}$

${ }^{\dagger}$ Biotechnology and Biodiversity Center Research (BIOTEC), Federal University of Piauí, Campus of Parnaíba, Avenida São Sebastião, 64202-020, Parnaíba-PI, Brazil

${ }^{\ddagger}$ Department of Physiology and Pharmacology, Federal University of Ceará, R. Cel. Nunes of Melo, 60430-270, Fortaleza-CE, Brazil

${ }^{\S}$ Bruker BioSpin GmbH, Rheinstetten 76287, Germany

ABSTRACT: The aim of this study was to investigate the antinociceptive and anti-inflammatory activities of epiisopiloturine (1), an imidazole alkaloid found in the leaves of Pilocarpus microphyllus. The anti-inflammatory activity of $\mathbf{1}$ was evaluated using several agents that induce paw edema and peritonitis in Swiss mice. Paw tissue and peritoneal fluid samples were obtained to determine myeloperoxidase (MPO) activity or tumor necrosis factor (TNF)- $\alpha$ and interleukin (IL)- $1 \beta$ levels. The antinociceptive activity was evaluated by acetic acid-induced writhing, the hot plate test, and pain induction using formalin. Compared to vehicle treatment, pretreatment with $1(0.1,0.3$, and $1 \mathrm{mg} / \mathrm{kg}$, ip) of mice significantly reduced carrageenan-induced paw edema $(p<0.05)$. Furthermore, compound 1 at a dose of $1 \mathrm{mg} / \mathrm{kg}$ effectively inhibited edema induced by dextran sulfate, serotonin, and bradykinin, but had no effect on histamine-induced edema. The administration of $1(1 \mathrm{mg} / \mathrm{kg})$ following

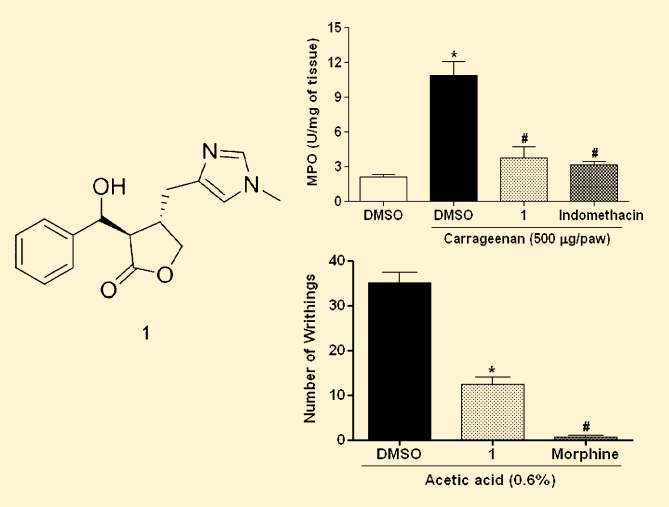
carrageenan-induced peritonitis reduced total and differential peritoneal leukocyte counts and also carrageenan-induced paw MPO activity and TNF- $\alpha$ and IL- $1 \beta$ levels in the peritoneal cavity. Pretreatment with 1 also reduced acetic acid-induced writhing and inhibited the first and second phases of the formalin test, but did not alter response latency in the hot plate test. Pretreatment with naloxone reversed the antinociceptive effect of 1 .

$\mathrm{T}$ he genus Pilocarpus, popularly known as "jaborandi", is one of the most important among the Brazilian flora, with native species in the north and northeast of the country. ${ }^{1}$ Pilocarpus microphyllus Stapf (Rutaceae) is the most well-known representative of the jaborandi group economically, because it contains high concentrations of the imidazole alkaloid pilocarpine, which is used to treat glaucoma, to stimulate the lachrymal and sweat glands, and to control xerostomia. ${ }^{2}$ In addition to pilocarpine, other imidazole alkaloids such as isopilosine, epiisopilosine, and epiisopiloturine (1) have been isolated from P. microphyllus. ${ }^{3}$ However, the biological properties of alkaloids such as $\mathbf{1}$ are still largely unknown.

The inflammatory process involves a complex cascade of biochemical and cellular events that occur in response to cellular injury. ${ }^{4}$ This process triggers formation of inflammatory neuromediators that activate nociceptors when released, facilitating pain transmission and peripheral inflammatory responses. ${ }^{5}$ Although a large number of analgesics and antiinflammatory agents are currently in clinical use, it would be useful to identify novel drugs having a wider specificity and lower toxicity than those currently available. ${ }^{4}$

The aim of the present study was to investigate the role of epiisopiloturine (1) in acute peripheral inflammation and in the analgesic processes induced by intraplantar and intraperitoneal injection of different phlogistic agents.

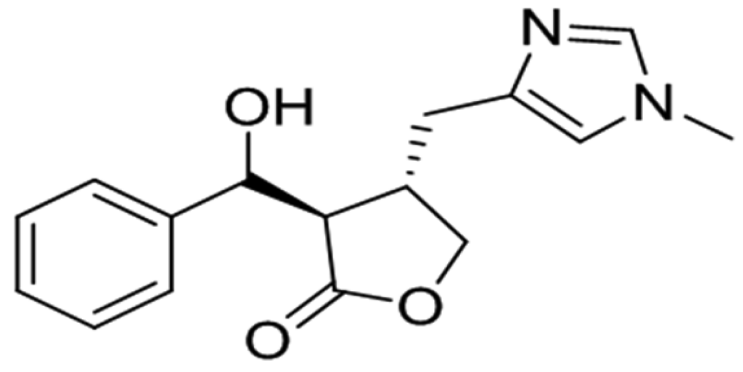

1

\section{RESULTS AND DISCUSSION}

The anti-inflammatory and antinociceptive potential of $\mathbf{1}$ was evaluated using a range of classical pharmacological models. The present results revealed that $\mathbf{1}$ possesses anti-inflammatory and antinociceptive activity in models of inflammation (paw edema

Received: February 4, 2013

Published: June 4, 2013 
Table 1. Effect of Epiisopiloturine (1) on Carrageenan-Induced Paw Edema in Mice ${ }^{a}$

\begin{tabular}{|c|c|c|c|c|c|}
\hline \multirow[b]{2}{*}{ treatment } & \multirow[b]{2}{*}{ dose $(\mathrm{mg} / \mathrm{kg})$} & \multicolumn{4}{|c|}{ paw edema $(\mathrm{mL})^{b}$} \\
\hline & & $1 \mathrm{~h}$ & $2 \mathrm{~h}$ & $3 \mathrm{~h}$ & $4 \mathrm{~h}$ \\
\hline $\mathrm{DMSO}^{c}$ & & $0.006 \pm 0.004$ & $0.004 \pm 0.004$ & $0.006 \pm 0.004$ & $0.004 \pm 0.004$ \\
\hline control & & $0.050 \pm 0.005^{\#}$ & $0.048 \pm 0.006^{\#}$ & $0.066 \pm 0.006^{\#}$ & $0.055 \pm 0.005^{\#}$ \\
\hline indomethacin $^{d}$ & 10 & $0.022 \pm 0.004 *(55.0)$ & $0.024 \pm 0.002 *(50.9)$ & $0.037 \pm 0.008^{*}(43.7)$ & $0.035 \pm 0.002(37.0)$ \\
\hline \multirow[t]{3}{*}{1} & 0.1 & $0.032 \pm 0.007 *(36.0)$ & $0.026 \pm 0.006^{*}(46.8)$ & $0.030 \pm 0.007 *(55.0)$ & $0.028 \pm 0.008^{*}(49.7)$ \\
\hline & 0.3 & $0.026 \pm 0.006 *(48.0)$ & $0.014 \pm 0.005^{*}(71.3)$ & $0.020 \pm 0.007 *(70.0)$ & $0.018 \pm 0.005^{*}(67.6)$ \\
\hline & 1.0 & $0.017 \pm 0.008 *(65.0)$ & $0.010 \pm 0.007^{*}(79.5)$ & $0.010 \pm 0.010 *(85.0)$ & $0.015 \pm 0.015^{*}(73.0)$ \\
\hline
\end{tabular}

${ }^{a}$ Edema was measured 1, 2, 3, and $4 \mathrm{~h}$ after carrageenin administration. ${ }^{b}$ Values of paw edema expressed as mean \pm SEM $(n=5)$. Percent inhibition of paw edema is indicated in parentheses. Control = carrageenan. ${ }^{\sharp} p<0.05$ vs DMSO group. ${ }^{*} p<0.05$ vs control. ${ }^{c}$ Negative control for edema. ${ }^{d}$ Positive control for edema.
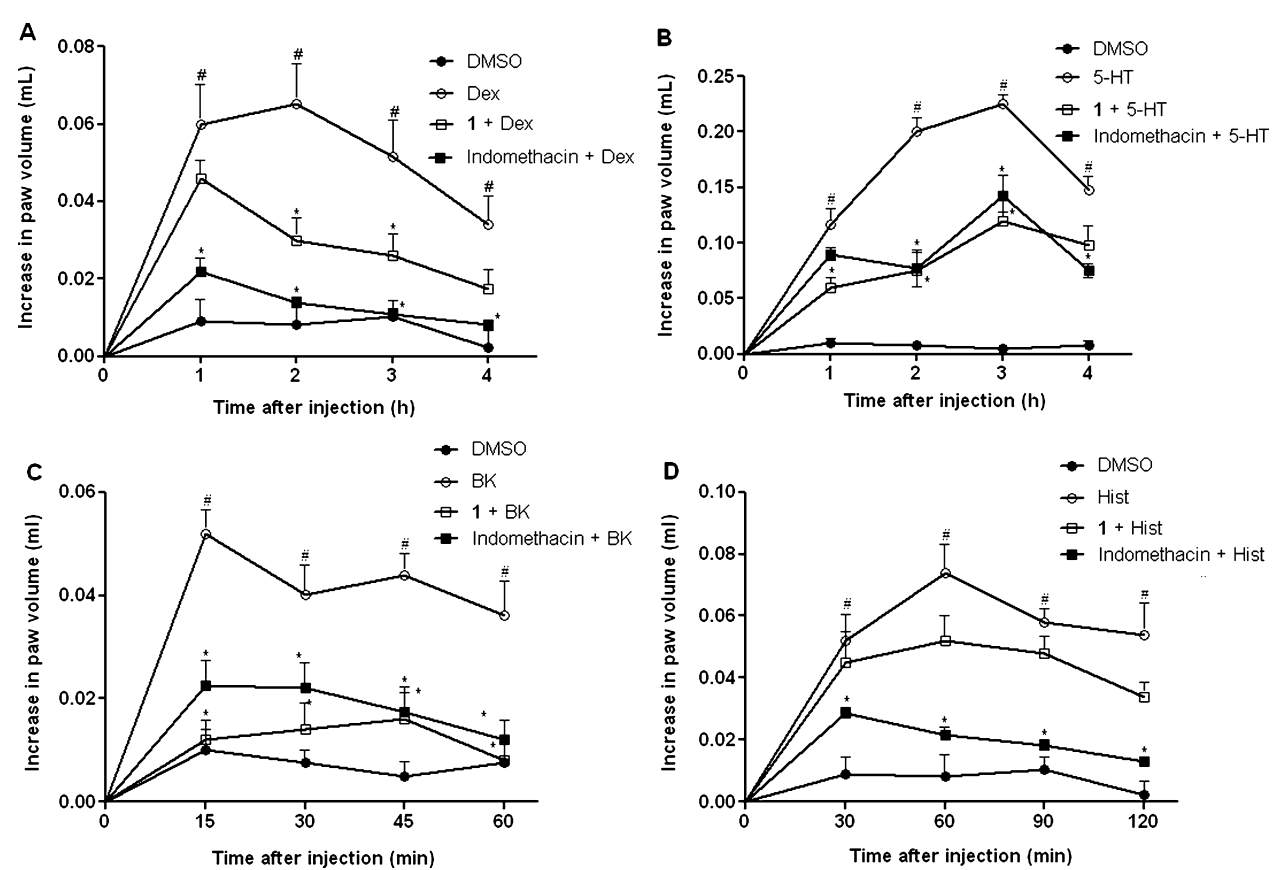

Figure 1. Effects of epiisopiloturine (1) on paw inflammation induced by different inflammatory agents. Edema was induced by (A) dextran sulfate (Dex); (B) serotonin (5-HT); (C) bradykinin (BK); and (D) histamine (Hist). Animals were pretreated with 1 (1 mg/kg ip), $2 \%$ dimethyl sulfoxide (DMSO; control, ip), or indomethacin $\left(10 \mathrm{mg} / \mathrm{kg}\right.$, ip). Each point represents the mean \pm SEM of five to six animals $\left({ }^{\#} p<0.05\right.$ compared to the DMSO group; $* p<0.05$ significantly different from the control group).

and neutrophil migration) and pain (acetic acid-induced writhing and the hot plate and the formalin tests).

Inflammation is a primary response of an organism to injurious stimuli, and some of these responses are characterized by pain, heat, redness, edema, and loss of function. ${ }^{6}$ Among these effects, edema and pain are fundamental and essential outcomes to be considered when evaluating potential anti-inflammatory and antinociceptive compounds.

The generation of carrageenan-induced mice paw edema is a widely used test to determine the anti-inflammatory activity of test compounds. ${ }^{8}$ Carrageenan injection into the mouse paw induces a biphasic edema: the first phase is characterized by an edema of little intensity and diffuse cellular infiltrate with a predominance of neutrophils that are capable of amplifying the inflammatory response via production of reactive oxygen species and release of inflammatory mediators; the second phase develops after $24 \mathrm{~h}$, displaying a more pronounced edema with a maximum effect between 48 and $72 \mathrm{~h}$ with an intense accumulation of macrophages, eosinophils, and lymphocytes. ${ }^{9}$

In the present experiments, the anti-inflammatory effect of 1 was investigated in the first phase of carrageenan-induced paw edema. It was shown that carrageenan induced severe paw edema occurring $1 \mathrm{~h}$ after injection, which was maintained for $4 \mathrm{~h}$ thereafter. There was a gradual increase in paw volume resulting from edema in the carrageenan-treated group, with a maximum value observed at $3 \mathrm{~h}$. Indomethacin $(10 \mathrm{mg} / \mathrm{kg}$, ip) suppressed paw edema significantly between 1 and $3 \mathrm{~h}$ after administration, with a maximal inhibition of $55.0 \%$ (first hour). Pretreatment with 1 induced significant inhibition of paw edema throughout the experimental period. At $3 \mathrm{~h}$, compared to the carrageenantreated mice, the animals pretreated with 1 at $0.1,0.3$, and $1 \mathrm{mg} / \mathrm{kg}$ showed maximal reductions in edema of 55.0, 70.0, and $85.0 \%$, respectively (Table 1). Since 1 at a dose of $1 \mathrm{mg} / \mathrm{kg}$ afforded the maximum protection against carrageenan-induced paw edema, this dose was selected for subsequent studies.

The development of phase 1 edema induced by carrageenan also involves the rapid production of various inflammatory mediators such as histamine, serotonin, and bradykinin. ${ }^{8}$ To investigate the potential of $\mathbf{1}$ to reduce edema, its effects on paw edema induced by different inflammatory mediators were evaluated. The administration of dextran sulfate (0.065 \pm $0.010 \mathrm{~mL}$; Figure 1A), serotonin $(0.225 \pm 0.008 \mathrm{~mL}$; Figure $1 \mathrm{~B})$, 
bradykinin $(0.052 \pm 0.004 \mathrm{~mL}$; Figure $1 \mathrm{C})$, or histamine $(0.074$ $\pm 0.009 \mathrm{~mL}$; Figure 1D) produced edema over time. In contrast, paw volumes in the control DMSO-injected group were $0.008 \pm$ $0.007 \mathrm{~mL}, 0.005 \pm 0.002 \mathrm{~mL}, 0.010 \pm 0.004 \mathrm{~mL}$, and $0.008 \pm$ $0.007 \mathrm{~mL}$, respectively. Pretreatment with $1(1 \mathrm{mg} / \mathrm{kg})$ effectively inhibited paw edema induced by dextran sulfate (54.08\% inhibition; Figure 1A), serotonin (46.66\% inhibition; Figure 1B), and bradykinin (76.92\% inhibition; Figure 1C) ( $p<$ $0.05)$. However, 1 did not inhibit paw edema induced by histamine (Figure 1D). The reference drug, indomethacin (10 mg/kg, ip), inhibited paw edema induced by all these inflammatory mediators significantly (Figure 1).

Dextran sulfate is known to promote inflammation by increasing vascular permeability, because of mast cell degranulation and the subsequent release of histamine and serotonin. ${ }^{10}$ In the present study, it was observed that $\mathbf{1}$ inhibited paw edema induced by dextran sulfate, serotonin, and bradykinin, but not by serotonin. These results suggested that the antiedematogenic effects of $\mathbf{1}$ are related to inflammatory events involving neutrophil migration, as well as inhibition of the release or activity of inflammatory mediators.

One inflammatory event of great importance in carrageenaninduced paw edema is the migration of leukocytes, primarily neutrophils. ${ }^{11}$ This response can be measured using the neutrophil-specific enzyme myeloperoxidase (MPO), which is an indicator of neutrophil accumulation. ${ }^{12}$ MPO can be released on the outside of the cell, inducing damage to adjacent tissue and thus contributing to the pathogenesis of inflammation. ${ }^{13}$ The results obtained showed that carrageenan produced a marked increase in MPO activity $(10.9 \pm 1.2 \mathrm{U} / \mathrm{mg}$ of tissue $)$. This increase was reduced by treatment with indomethacin $(3.1 \pm 0.3 \mathrm{U} / \mathrm{mg}$ of tissue), the positive control. The administration of $1(3.8 \pm 0.9 \mathrm{U} / \mathrm{mg}$ of tissue) also reduced MPO activity, suggesting that its antiinflammatory action may involve inhibition of leukocyte migration and neutrophil infiltration (Figure 2). A direct relationship between

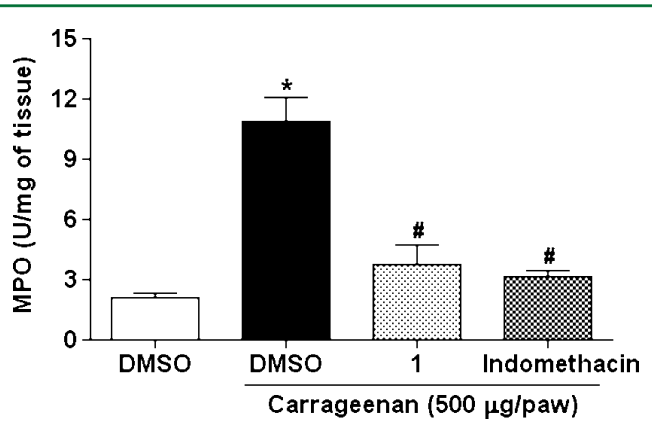

Figure 2. Effect of epiisopiloturine (1) on carrageenan-induced paw tissue myeloperoxidase (MPO) activity. Mice were injected with $2 \%$ dimethyl sulfoxide (DMSO) ip or carrageenan. Thirty minutes earlier, $1(1 \mathrm{mg} / \mathrm{kg}$, ip $)$ or indomethacin $(10 \mathrm{mg} / \mathrm{kg}$, ip $)$ was administered to the animals. The control group (DMSO) was treated only with DMSO. MPO activity in the paw tissue was determined after $4 \mathrm{~h}$. Results are expressed as the mean \pm SEM for at least five or six animals per group ( $*_{p}<0.05$ compared to the DMSO plus carrageenan group).

tissue neutrophil concentration and MPO activity has been reported, ${ }^{14}$ and the anti-inflammatory activities of certain compounds have been attributed, in part, to the inhibition of MPO activity. ${ }^{15}$

Leukocytes play an important role in acute inflammatory processes, and tissue damage is a deleterious consequence of intense neutrophil migration, as observed in inflammatory diseases. ${ }^{16}$ Compound 1 was evaluated to determine if it can inhibit cell recruitment into the peritoneal cavity in carrageenaninduced peritonitis. This experimental model provides a wellcharacterized pharmacological tool to examine acute peritoneal inflammation, which allows quantification of cell migration, resident macrophage activation, and levels of several inflammatory mediators. ${ }^{17}$

In the present study, administration of carrageenan promoted the formation of an intense cellular infiltrate (Figure 3). Carrageenan
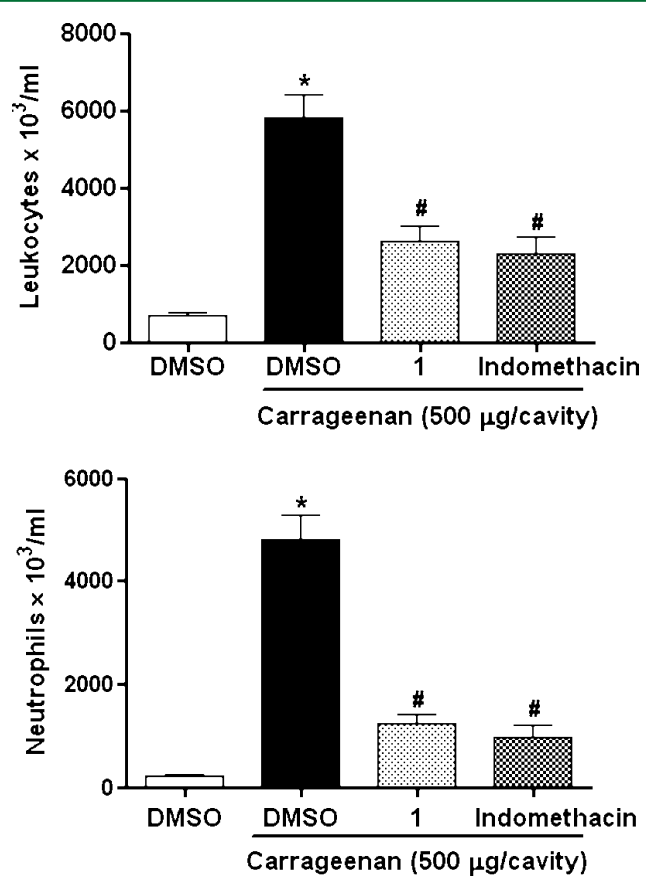

Figure 3. Anti-inflammatory effect of epiisopiloturine (1) on neutrophil migration in mice. Mice were injected ip with dimethyl sulfoxide (DMSO), 1 $(1 \mathrm{mg} / \mathrm{kg})$, or indomethacin $(10 \mathrm{mg} / \mathrm{kg}$, reference control $)$ and were injected with $250 \mu \mathrm{L}$ of carrageenan (500 $\mu \mathrm{g} /$ cavity, ip) $30 \mathrm{~min}$ later. Neutrophil migration was evaluated after $4 \mathrm{~h}$. The white bars represent the peritoneal neutrophils in animals injected with DMSO (untreated group). (A) Total counts and (B) differential counts. The values are means \pm SEM of five or six animals for each group $\left({ }^{*} p<0.05\right.$ compared to the DMSO group; ${ }^{*} p<0.05$ compared to the carrageenan group).

( $500 \mu \mathrm{g} /$ cavity) induced cell migration into the peritoneal cavity $4 \mathrm{~h}$ after administration, with a total leukocyte count of $(5.81 \pm 0.61 \times$ $10^{6}$ cells $/ \mathrm{mL}$ ) (Figure $3 \mathrm{~A}$ ). However, the administration of 1 $(1 \mathrm{mg} / \mathrm{kg}$, ip) $30 \mathrm{~min}$ before carrageenan reduced this peritoneal leukocyte count to $\left(2.60 \pm 0.61 \times 10^{6}\right.$ cells $\left./ \mathrm{mL}\right)$, a $55.2 \%$ inhibition. The same dose of 1 also reduced neutrophil migration into the peritoneal cavity $\left(1.26 \pm 0.17 \times 10^{6}\right.$ cells $\left./ \mathrm{mL}\right), 73.8 \%$ lower than the control group $\left(5.82 \pm 0.47 \times 10^{6}\right.$ cells $\left./ \mathrm{mL}\right)$ (Figure $\left.3 \mathrm{~B}\right)$. Similarly, when compared to carrageenan treatment, pretreatment with indomethacin produced a $60.2 \%$ reduction in total leukocyte count and a $79.6 \%$ reduction in neutrophil migration to the peritoneal cavity.

Previous studies have demonstrated that carrageenan injection into the peritoneal cavity induces the release of certain proinflammatory cytokines, such as TNF $\alpha$ and IL- $1 \beta .{ }^{15}$ As shown in Figure 4, the ip administration of carrageenan induced a marked increase in TNF- $\alpha$ and IL1- $\beta$ concentrations in the peritoneal fluid. Pretreatment of animals with $1(1 \mathrm{mg} / \mathrm{kg}$, ip) reduced TNF- $\alpha$ (Figure 4A) and IL1- $\beta$ (Figure 4B) levels significantly.

Cytokines have been shown to have many biological activities in the inflammatory response, including accumulation of 

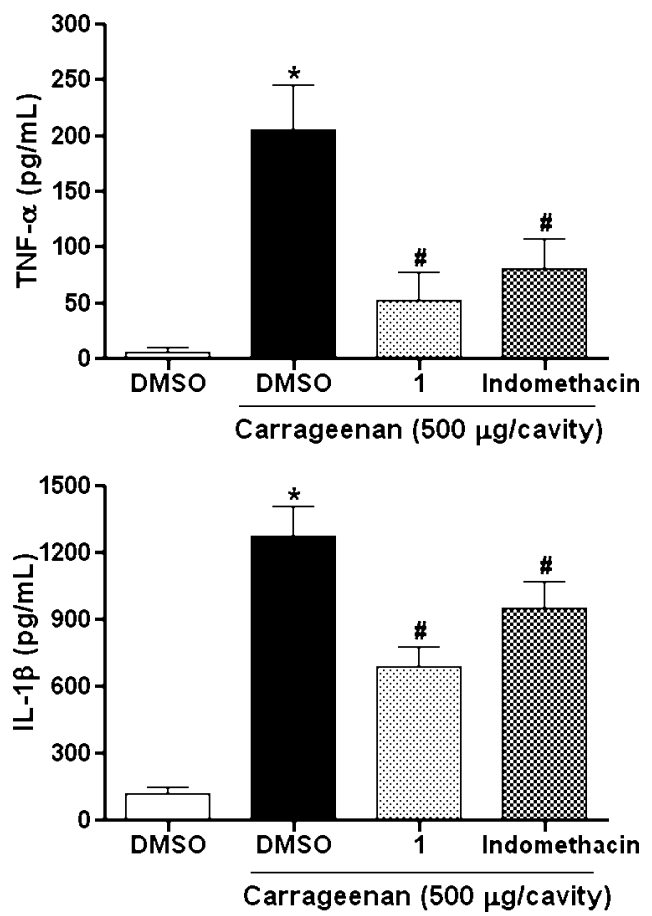

Figure 4. Effect of epiisopiloturine (1) on carrageenan-induced cytokine production in peritonitis. Levels of tumor necrosis factor (TNF)- $\alpha$ (A), interleukin (IL)- $1 \beta$ (B), in the peritoneal cavity were measured $4 \mathrm{~h}$ after carrageenan injection. Mice were administered $1(1 \mathrm{mg} / \mathrm{kg}$, ip) and $250 \mu \mathrm{L}$ of carrageenan $(500 \mu \mathrm{g} /$ cavity, ip) $1 \mathrm{~h}$ later. Each point represents the mean \pm SEM of five or six animals for each group $(* p<0.05$ compared to dimethyl sulfoxide (DMSO)-treated animals; $\# p<0.05$ compared to the carrageenan group).

neutrophils in local tissues and induction of acute-phase protein synthesis. ${ }^{18}$ Thus, on the basis of literature precedent and current data, it can be inferred that the anti-inflammatory effect of $\mathbf{1}$ is dependent, at least in part, on inhibition of neutrophil infiltration and the release of the pro-inflammatory cytokines TNF- $\alpha$ and $\mathrm{IL}-1 \beta$.

Considering the relationship between inflammation and the development of a painful sensation, it was decided to investigate the antinociceptive effects of $\mathbf{1}$, using three pain models (acetic acid-induced writhing, the hot plate test, and the formalininduced nociception test for peripheral and central activity).

Acetic acid-induced writhing is a visceral pain model widely used to screen antinociceptive potential. ${ }^{19}$ The ip administration of this agent irritates the serous membranes and provokes a stereotypical behavior in experimental animals, characterized by abdominal contractions, movement of the body as a whole, and twisting of the dorsal abdominal muscles. ${ }^{20}$ This model involves a range of nociceptive mechanisms, such as release of biogenic amines (e.g., bradykinin and serotonin), cyclooxygenases, and their metabolites (e.g., PGE2 and PGF2 $\alpha$ ), ${ }^{21}$ activation of peritoneal receptors and inflammatory pain by induction of capillary permeability, ${ }^{22}$ reduction of nociception threshold, and stimulation of nociceptive nerve terminals. ${ }^{23}$ Recent evidence has suggested that spinal MAP kinases and other signaling pathways in the spinal cord mediate the acetic acid-induced writhing response in mice. ${ }^{24}$

In the present study, pretreatment with $1(1 \mathrm{mg} / \mathrm{kg}$, ip), $30 \mathrm{~min}$ prior to acetic acid administration, produced inhibition of the abdominal writhing response by $66.4 \%(p<0.05)$. Compared to the group administered with acetic acid only, the morphine (reference drug)-administered group showed a reduction in writhing movements by $98.3 \%$ (Figure 5). These results suggested

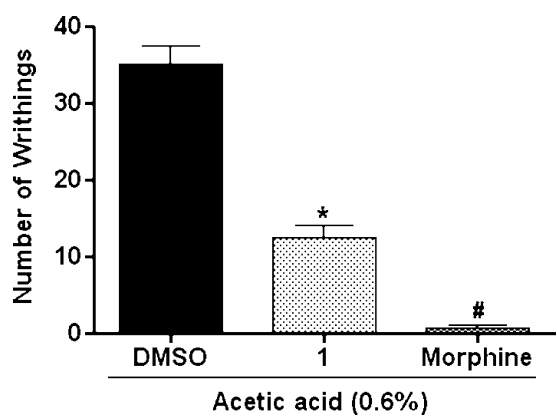

Figure 5. Effect of epiisopiloturine (1) on the writhing response induced by acetic acid in mice. Mice received dimethyl sulfoxide (DMSO), 1 $(1 \mathrm{mg} / \mathrm{kg}$, ip), or morphine $(5 \mathrm{mg} / \mathrm{kg}$, ip; reference control), $30 \mathrm{~min}$ prior to $0.6 \%$ acetic acid $(250 \mu \mathrm{L} /$ cavity; ip). Data are expressed as the means \pm SEM of five or six animals for each group $(* p<0.05$ indicates a significant difference from the acetic acid group).

that $\mathbf{1}$ may reduce inflammatory mediator release or block inflammation-promoting receptors.

In order to confirm the antinociceptive activity and investigate the involvement of central mechanisms on the effects of 1 , the hot plate test was performed according to a protocol described previously. ${ }^{25}$ This test is a well-known model for acute thermal nociception, is used to evaluate specifically central nociception, ${ }^{26}$ and measures complex responses to inflammation and nociception, ${ }^{27}$ in which opioid agents exert their analgesic effects via supraspinal and spinal receptors. ${ }^{28}$ The present results showed that treatment with 1 $(1 \mathrm{mg} / \mathrm{kg}$, ip) failed to modify the hot plate response, indicating that it does not act centrally. On the other hand, treatment with morphine $(5 \mathrm{mg} / \mathrm{kg}, \mathrm{sc})$, an opioid receptor agonist, induced a significant increase in latency time in the hot plate test, as expected, which persisted for at least $120 \mathrm{~min}$ (Figure 6).

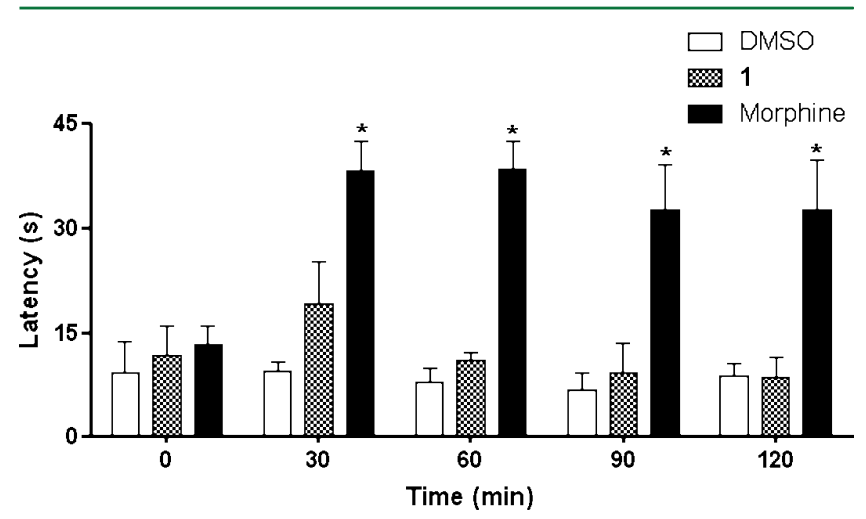

Figure 6. Effect of epiisopiloturine (1) on reaction times to thermal stimuli (hot plate). Mice received dimethyl sulfoxide (DMSO), 1 (1 mg/kg, ip), or morphine $(5 \mathrm{mg} / \mathrm{kg}, \mathrm{sc})$. Data are expressed as the means \pm SEM of five or six animals for each group $\left({ }^{*} p<0.05\right.$ when compared with the time zero).

The rota-rod apparatus was used to assess whether treatment with 1 could influence the motor activity of the animals and consequently impair the assessment of the nociceptive behavior in experimental models. ${ }^{29}$ Using the rota-rod test, mice treated with 1 did not demonstrate any significant motor performance changes, while diazepam significantly increased the number of falls (data not shown).

To distinguish between the peripheral and central antinociceptive actions of 1 , the formalin test was performed. In this test, a peripheral noxious stimulus causes a distinct biphasic nociceptive response involving two mechanisms. The first phase (neurogenic 
pain) seems to be caused by the direct effect of formalin on sensory C-fibers that reflect centrally mediated pain, with the release of substance $P{ }^{30}$ The direct activation of primary sensory fibers by formalin also involves release of mediators such as histamine and serotonin. ${ }^{31}$ The second phase (inflammatory pain) involves a combination of inflammatory and nociceptive mediators released from injured tissues, such as prostaglandins, serotonin, histamine, and bradykinin, responsible for sensitization of primary and spinal sensory neurons and subsequent activation of the nociceptors. ${ }^{30}$

The results obtained demonstrated that mice treated with $2.5 \%$ formalin had mean licking times of $65.55 \pm 20.23 \mathrm{~s}$ in the first phase (neurogenic; $0-5 \mathrm{~min}$; Figure $7 \mathrm{~A}$ ) and $35.88 \pm 12.39 \mathrm{~s}$ in the second phase (inflammatory; 20-25 min; Figure 7B).
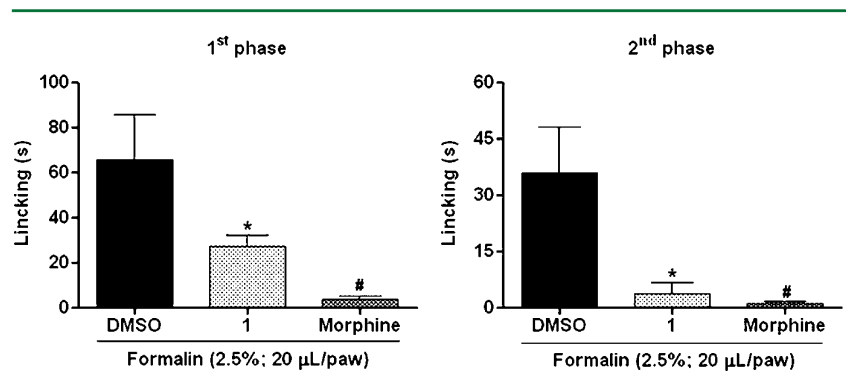

Figure 7. Effect of epiisopiloturine (1) on the formalin test in mice. The time spent licking was determined during the first $0-5 \min$ (phase 1; panel A) and during 20-25 min (phase 2; panel B) after injection with $2.5 \%$ formalin. Dimethyl sulfoxide (DMSO), 1 ( $1 \mathrm{mg} / \mathrm{kg}$, ip), or morphine $(5 \mathrm{mg} / \mathrm{kg}$, ip; positive control) were administered $30 \mathrm{~min}$ before intradermal administration of formalin. Data are expressed as the mean \pm SEM of five or six animals for each group $(* p<0.05$ indicates significant difference from the formalin group).

Pretreatment with 1 ( $1 \mathrm{mg} / \mathrm{kg}$, ip) reduced paw licking induced by intraplantar administration of formalin significantly in both test phases: the neurogenic (phase 1,58.18\% reduction) and the inflammatory (phase 2, $89.21 \%$ reduction) phases. Similarly, morphine $(5 \mathrm{mg} / \mathrm{kg}, \mathrm{sc})$ inhibited both phases of the formalin test (94.0\% and $97.21 \%$ reduction in phase 1 and 2, respectively) (Figure 7). These results corroborated those obtained in the paw edema model. In this test, pretreatment with 1 inhibited paw edema induced by serotonin and bradykinin, which are important mediators involved in both phases of formalin-induced nociception.

In the formalin test, a decrease in licking time in both phases is characteristic of drugs that act centrally and indicates a possible interaction with opioid receptors, while peripherally acting drugs, such as nonsteroidal anti-inflammatory drugs and corticosteroids, inhibit only the second phase. ${ }^{32}$ The effect of $\mathbf{1}$ on both phases of the formalin test suggested that it acts peripherally and centrally to reduce inflammatory pain.

To better understand the antinociceptive effect of epiisopiloturine (1), the formalin first phase was evaluated in animals pretreated with or without naloxone. It was interesting to note that pretreatment with naloxone, an opioid-receptor antagonist, ${ }^{33}$ reversed the antinociceptive effect of 1 (Figure 8 ). Thus, 1 seems to possess antinociceptive mechanisms that are partially mediated by the activation of the opioid system.

\section{EXPERIMENTAL SECTION}

General Experimental Procedures. A ${ }^{1} \mathrm{H}$ NMR spectrum was acquired on an AVANCE III NMR spectrometer $(600 \mathrm{MHz})$, equipped with a $5 \mathrm{~mm}$ TXI probe head (Bruker Biospin, Rheinstetten, Germany). An AmaZon SL mass spectrometer was used (Bruker Daltonics,

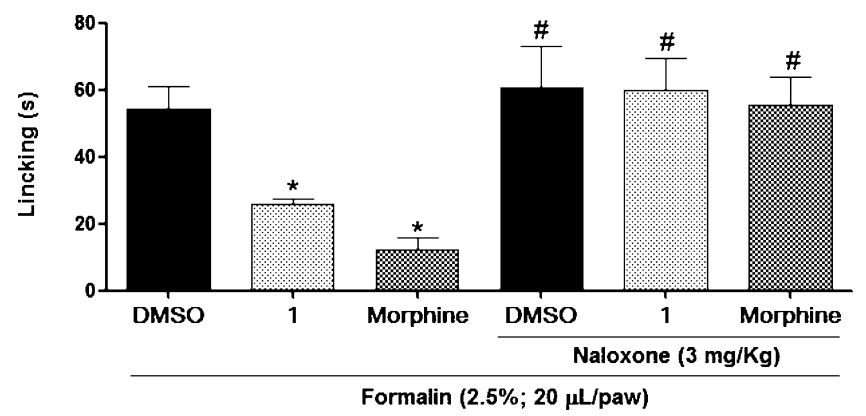

Figure 8. Effect of pretreatment with naloxone $(3 \mathrm{mg} / \mathrm{kg}, \mathrm{sc})$ on the analgesic effect of epiisopiloturine (1) on the formalin test. Mice were pretreated with $2 \%$ DMSO or naloxone $(3 \mathrm{mg} / \mathrm{kg}$, sc, opioid antagonist). After $30 \mathrm{~min}$, the animals were treated with 1 (1 mg/kg, ip) or morphine (5 $\mathrm{mg} / \mathrm{kg}, \mathrm{sc}$ ). After $60 \mathrm{~min}$, the time spent licking was determined during the first $0-5 \mathrm{~min}$ (phase 1) after injection with $2.5 \%$ formalin. Data are expressed as the means \pm SEM of six animals for each group $(* p<0.05$ indicates significant difference from the formalin group; ${ }^{\#} p<0.05$ indicates significant difference from the respective group).

Bremen, Germany). A Shimadzu HPLC instrument was employed for compound purification, with a LiChrospher 60 RP Select B column.

Plant Material. A specimen of Pilocarpus microphyllus was collected in October 2008 near Matias Olimpio city (Piaui, Brazil) and was identified by Dr. Ivanilza Moreira de Andrade, Department of Biology, Federal University of Piauí. A voucher specimen (TEPB 27.152) was deposited at the Graziella Barroso Herbarium (Teresina, Piaui, Brazil).

Extraction and Isolation. Epiisopiloturine (1) was obtained from waste produced by pilocarpine extraction from P. microphyllus leaves according to Veras et al. ${ }^{34}$ The organic phase was submitted to liquidliquid extraction, alkalinized with ammonium hydroxide solution to precipitate the $\mathbf{1}$ in the neutral form, and then the solution was filtered under reduced pressure. ${ }^{35}$ After further workup, 1 was shown to be pure by HPLC (>95\% w/w) and exhibited ${ }^{1} \mathrm{H}$ NMR and MS/MS data consistent with literature values. ${ }^{36,37}$

Drugs and Reagents. $\lambda$-Carrageenan, indomethacin, bradykinin, serotonin, dextran sulfate, histamine, captopril, acetic acid, formaldehyde, and dimethyl sulfoxide (DMSO) were purchased from Sigma Chemical (Saint Louis, MO, USA). Heparin and morphine were provided by Merck, São Paulo, Brazil. All drugs were dissolved in sterile $0.9 \%(\mathrm{w} / \mathrm{v}) \mathrm{NaCl}$ (saline). The epiisopiloturine (1) was dissolved in $2 \%$ DMSO. All other chemicals were of analytical grade and obtained from standard commercial suppliers.

Animals. Male Swiss mice $(25-30 \mathrm{~g})$ were housed at a temperature of $25 \pm 2{ }^{\circ} \mathrm{C}$ under a $12 / 12 \mathrm{~h}$ light/dark cycle with food and water ad libitum. Animals were fasted for $18-24 \mathrm{~h}$ before the experiments. All experiments were performed in accordance with the Guide for Care and Use of Laboratory Animals (National Institute of Health, Bethesda, MD, USA) and were approved by the Ethics Committee in Research of the Federal University of Piaui (protocol no. 0066/10).

Carrageenan-Induced Paw Edema. The animals were randomly divided into six groups $(n=5)$, and edema was induced by injection of $50 \mu \mathrm{L}$ of a suspension of carrageenan $(500 \mu \mathrm{g} / \mathrm{paw})$ in $0.9 \%$ sterile saline into the right hind paw (group I). Mice were pretreated intraperitoneally (ip) with either $2 \%$ DMSO (group II untreated control), indomethacin $10 \mathrm{mg} / \mathrm{kg}$ (group III reference control), or epiisopiloturine (1) 0.1, 0.3, or $1 \mathrm{mg} / \mathrm{kg}$ (groups IV, V, and VI, respectively). Paw volume was measured immediately before $\left(V_{\mathrm{o}}\right)$ and at $1,2,3$, and $4 \mathrm{~h}$ after carrageenan treatment $\left(V_{\mathrm{t}}\right)$ using a plethysmometer (Panlab, Barcelona, Spain), as previously described. ${ }^{38}$ The effect of pretreatment was calculated as percent inhibition of edema relative to the paw volume of the DMSO-treated controls by using the following formula: ${ }^{39}$

$$
\text { \%inibition of edema }=\frac{\left(V_{\mathrm{t}}-V_{\mathrm{o}}\right)_{\text {control }}-\left(V_{\mathrm{t}}-V_{\mathrm{o}}\right)_{\text {treated }}}{\left(V_{\mathrm{t}}-V_{\mathrm{o}}\right)_{\text {control }}} \times 100
$$

Paw Edema Induced by Different Inflammatory Agents. To induce edema, the animals were administered $50 \mu \mathrm{L}$ injections of 
dextran sulfate (DEX; $500 \mu \mathrm{g} /$ paw), bradykinin (BK; $6.0 \mathrm{nmol} / \mathrm{paw})$, serotonin (5-HT; 1\% w/v), or histamine (HIST; $100 \mu \mathrm{g} / \mathrm{paw}$ ) into the right hind paw, as adapted from the reports of Barbosa et al. ${ }^{40}$ and Vasconcelos et al. ${ }^{40}$ The contralateral paw received $50 \mu \mathrm{L}$ of $2 \%$ DMSO and served as an untreated control. In the experiment with bradykinin, the animals were pretreated with captopril $(5 \mathrm{mg} / \mathrm{kg}$, ip) $1 \mathrm{~h}$ prior to bradykinin induction to prevent bradykinin degradation. ${ }^{42}$ Epiisopiloturine $(1)(1 \mathrm{mg} / \mathrm{kg})$ or indomethacin $(10 \mathrm{mg} / \mathrm{kg}$, reference control) was injected ip $30 \mathrm{~min}$ before these intraplantar injections of phlogistic agents.

Myeloperoxidase Activity. MPO is an enzyme found primarily in neutrophil azurophilic granules that has been used extensively as a biochemical marker for granulocyte infiltration into tissues, including paw tissue. ${ }^{43}$ MPO activity was determined to evaluate neutrophil accumulation in the mouse paw. Briefly, 50-100 mg of paw tissue was homogenized in potassium phosphate buffer containing $0.5 \%$ hexadecyltrimethylammomium bromide. The homogenate was centrifuged at $40000 \mathrm{~g}$ for $7 \mathrm{~min}$ at $4{ }^{\circ} \mathrm{C}$. The pellet was resuspended, and MPO activity was assayed by measuring the change in absorbance at $450 \mathrm{~nm}$ using $o$-dianisidine dihydrochloride and $1 \%$ hydrogen peroxide. MPO activity is reported as units/mg of tissue. A unit of MPO activity was defined as that converting $1 \mu \mathrm{mol}$ of hydrogen peroxide to water in $1 \mathrm{~min}$ at $22^{\circ} \mathrm{C}$.

Evaluation of Neutrophil Migration. For the determination of neutrophil migration into the peritoneal cavity, mice were injected intraperitoneally with $2.0 \% \mathrm{DMSO}$, indomethacin $10 \mathrm{mg} / \mathrm{kg}$, or epiisopiloturine (1) $1 \mathrm{mg} / \mathrm{kg}$. Thirty minutes later, the animals were injected with carrageenan $(250 \mu \mathrm{L} ; 500 \mu \mathrm{g} /$ cavity $)$. Mice were euthanized $4 \mathrm{~h}$ later, and the peritoneal cavity was washed with $1.5 \mathrm{~mL}$ of heparinized phosphate-buffered saline (PBS) to harvest peritoneal cells. The volumes recovered were similar in all experimental groups and were equivalent to $\sim 95 \%$ of the injected volume. Total cell counts were performed in a Neubauer chamber, and differential cell counts (100 cells total) were carried out on cytocentrifuge slides stained with hematoxylin and eosin. The results are presented as the number of neutrophils per milliliter of peritoneal exudate. Aliquots of the peritoneal exudates were stored at $-70^{\circ} \mathrm{C}$ for later analysis of cytokine content.

Cytokine Measurements. The levels of TNF- $\alpha$ and IL- $1 \beta$ were evaluated using sandwich ELISA. Briefly, microliter plates were coated overnight at $4{ }^{\circ} \mathrm{C}$ with antibody against mice TNF- $\alpha$ or IL- $1 \beta(2 \mu \mathrm{g} /$ $\mathrm{mL}$ ). Blocking of nonspecific binding sites was accomplished by incubating plates with PBS containing $2 \%$ BSA for 90 min at $37^{\circ} \mathrm{C}$. After blocking the plates, the test samples and each standard at various dilutions were added in duplicate and incubated at $4{ }^{\circ} \mathrm{C}$ for $24 \mathrm{~h}$. The plates were washed three times with buffer. After washing the plates, $50 \mu \mathrm{L}$ of biotinylated sheep polyclonal anti-TNF- $\alpha$, anti-IL- $1 \beta$, (diluted $1: 1000$ with assay buffer $1 \%$ BSA) was added to the wells. After further incubation at room temperature for $1 \mathrm{~h}$, the plates were washed, and $50 \mu \mathrm{L}$ of streptavidin-HRP diluted 1:5000 was added to all wells. The reagent $o$-phenylenediamine dihydrochloride $(50 \mu \mathrm{L})$ was added $15 \mathrm{~min}$ later, and the plates were incubated in the dark at $37^{\circ} \mathrm{C}$ for $15-20 \mathrm{~min}$. After color development, the reaction was stopped with the addition of sulfuric acid (1 M), and absorbance was measured at $490 \mathrm{~nm}$. The results are expressed as $\mathrm{pg} / \mathrm{mg}$ protein and reported as mean $\pm \mathrm{SD}$.

Writhing Test. Acetic acid administration causes irritation, resulting in painful contortions, followed by hind limb extension. Each experimental group was pretreated with DMSO, epiisopiloturine (1) $(1 \mathrm{mg} / \mathrm{kg}$, ip), or morphine $(5 \mathrm{mg} / \mathrm{kg}$, sc, reference control). After $30 \mathrm{~min}$, $0.6 \%$ acetic acid $(10 \mathrm{~mL} / \mathrm{kg}$ body weight, ip) was administered. After waiting for $10 \mathrm{~min}$, the number of constrictions, including abdominal muscle contractions and hind paw extension, was recorded over $20 \mathrm{~min}$, as described by Koster et al. ${ }^{44}$

Hot Plate Test. The mice were treated according to the method described by Eddy and Leinback. ${ }^{26}$ Each mouse was dropped twice on a heated plate $\left(55 \pm 1{ }^{\circ} \mathrm{C}\right)$, separated by a $30 \mathrm{~min}$ interval. The first trial familiarized the animal with the test procedure, and the second served as the control reaction time (licking of a paw or jumping), recorded as the response latency on a hot plate (Insight, Ribeirão Preto, São Paulo, Brazil; model EFF-361). Animals with baseline latencies of more than $20 \mathrm{~s}$ were excluded from the study. The mice were treated with epiisopiloturine (1) $(1 \mathrm{mg} / \mathrm{kg}$, ip) or morphine $(5 \mathrm{mg} / \mathrm{kg}$, sc; reference drug) $30 \mathrm{~min}$ before the test, and the control group received the same volume of $2 \%$ DMSO. Measurements were performed before (zero time) and 30, 60, 90, and 120 min after treatment, with a cut-off time of $45 \mathrm{~s}$ to prevent development of paw lesion.

Formalin Test. The mice were pretreated with either $2 \% \mathrm{DMSO}$ epiisopiloturine (1) $(1 \mathrm{mg} / \mathrm{kg}$, ip), or morphine $(5 \mathrm{mg} / \mathrm{kg}$, sc; reference control). Thirty minutes after administration, $2.5 \%$ formalin $(20 \mu \mathrm{L})$ was administered intradermally (id) into the right hind paw. Licking time was recorded from 0 to $5 \mathrm{~min}$ (phase 1, corresponding to a direct chemical stimulation of nociceptors) and $20-25 \mathrm{~min}$ after formalin injection (phase 2, involving release of inflammatory mediators). ${ }^{45}$

Evaluation of Opioid Pathway Involvement in the Antinociceptive Effect of Epiisopiloturine (1). To examine the involvement of opioid receptors in the antinociceptive activity of $\mathbf{1}$ for formalin-induced pain, mice $(n=6)$ were pretreated with $2 \%$ DMSO or naloxone $(3 \mathrm{mg} / \mathrm{kg}$, sc; opioid antagonist). After $30 \mathrm{~min}$, the animals were treated with $1(1 \mathrm{mg} / \mathrm{kg}$, ip) or morphine $(5 \mathrm{mg} / \mathrm{kg}$, sc; opioid agonist). Sixty minutes after administration, $2.5 \%$ formalin $(20 \mu \mathrm{L})$ was administered intradermally into the right hind paw. Licking time was recorded from 0 to $5 \mathrm{~min}$ (phase 1, corresponding to a direct chemical stimulation of nociceptors). ${ }^{46}$

Evaluation of Motor Activity. The rota-rod test permits the detection of muscle-relaxing agents or drugs that produce motor incoordination. Earlier, the animals were evaluated to select those that showed ability in walking on the revolving bar under the same conditions used in the test, and these were divided into groups $(n=6)$. On the day of the test, animals were treated by gavage with $0.5 \mathrm{~mL} / 25 \mathrm{~g}$ vehicle ( $2 \%$ DMSO, control), 1 (1 or $10 \mathrm{mg} / \mathrm{kg}$ ), or diazepam $(5 \mathrm{mg} / \mathrm{kg}$, positive control for motor impairment). After $60 \mathrm{~min}$, the animals were placed on the horizontal rotating bar $(12 \mathrm{rpm})$, which was a nonslip plastic rod located $28 \mathrm{~cm}$ over the base, for $1 \mathrm{~min}$. The number of falls was counted, with a maximum of three replacements on the bar. ${ }^{47}$

Statistical Analysis. Results are expressed as means \pm SEM of at least five animals per group, and statistical analysis was performed using one-way analysis of variance (ANOVA) followed by the Newman-Keuls post hoc test, when appropriate. Statistical significance was set at $p<0.05$.

\section{AUTHOR INFORMATION}

\section{Corresponding Author}

*Tel: +55-86-99862374/+55-86-33234750. Fax: +55-8633235406. E-mail: jandvenes@ufpi.edu.br.

\section{Notes}

The authors declare no competing financial interest.

\section{ACKNOWLEDGMENTS}

The authors gratefully acknowledge financial support from the National Counsel of Technological and Scientific Development, CNPq (Brazil); the Research Foundation for the State of Piaui, FAPEPI; Nanobiomed Network Capes/Brazil; ANIDRO do Brasil S.A.; and Phytobios. This work forms part of the requirements to obtain a Master of Science degree in Biotechnology, Federal University of Piaui, for V.G.S.

\section{REFERENCES}

(1) Santos, A. P.; Moreno, P. R. H. Braz. J. Pharm. Sci. 2004, 40, 115137.

(2) Pinheiro, C. U. Econ. Bot. 1997, 51, 49-58.

(3) Andrade-Neto, M.; Mendes, P. H.; Silveira, E. R. Phytochemistry 1996, 42, 885-887.

(4) Carvalho, W. A.; Lemônica, L. Rev. Bras. Anestesiol. 1998, 48, 137158.

(5) Wright, A. Manual Ther. 1999, 4, 196-202.

(6) Nathan, C. Nature 2002, 420, 846-852.

(7) Morris, C. J. Methods Mol. Biol. 2003, 225, 115-121.

(8) Seibert, K.; Zhang, Y.; Leahy, K.; Hauser, S.; Masferrer, J.; Perkins, W.; Lee, L.; Isakson, P. Proc. Natl. Acad. Sci. U.S.A. 1994, 91, 1201312017. 
(9) Henriques, M. G.; Silva, P. M.; Martins, M. A.; Flores, C. A.; Cunha, F. Q.; Assreuy-Filho, J.; Cordeiro, R. S. Braz. J. Med. Biol. Res. 1987, 20, 243-249.

(10) Rowley, D. A.; Benditt, E. P. J. Exp. Med. 1956, 103, 399-415.

(11) Carvalho, J. C.; Teixeira, J. R.; Souza, P.J.; Bastos, J. K.; dos Santos Filho, D.; Sarti, S. J. J. Ethnopharmacol. 1996, 53, 175-178.

(12) Ajuebor, M. N.; Singh, A.; Wallace, J. L. Am. J. Physiol. Gastrointest. Liver Physiol. 2000, 279, 238-244.

(13) Klebanoff, S. J. Proc. Assoc. Am. Physicians 1999, 111, 383-389.

(14) Van der Veen, B. S.; Winther, M. P.; Heeringa, P.; Augusto, O.; Chen, J. W.; Davies, M.; Ma, X. L.; Malle, E.; Pignatelli, P.; Rudolph, T. Antioxid. Redox Signaling 2009, 11, 2899-2937.

(15) Chaves, L. S.; Nicolau, L. A. D.; Silva, R. O.; Barros, F. C.; Freitas, A. L.; Aragão, K. S.; Ribeiro, R. A.; Souza, M. H. L. P.; Barbosa, A. L. R.; Medeiros, J. V. R. Immunopharmacol. Immunotoxicol. 2013, 35, 93-100.

(16) Smiderle, F. R.; Olsen, L. M.; Carbonero, E. R.; Baggio, C. H.; Freitas, C. S.; Marcon, R.; Santos, A. R. S.; Gorin, P. A. J.; Iacomini, M. Eur. J. Pharmacol. 2008, 597, 86-91.

(17) Montanher, A. B.; Zucolotto, S. M.; Schenkel, E. P.; Fröde, T. S. J. Ethnopharmacol. 2007, 109, 281-288.

(18) Pinheiro, M. M.; Fernandes, S. B.; Fingolo, C. E.; Boylan, F.; Fernandes, P. D. J. Ethnopharmacol. 2013, 7, 324-330.

(19) Utsunomiya, I.; Ito, M.; Oh-ishi, S. Cytokine 1998, 10, 956-963.

(20) Zeashan, H.; Amresh, G.; Rao, C. V.; Singh, S. J. Ethnopharmacol. 2009, 122, 492-496.

(21) Ribeiro, R. A.; Vale, M. L.; Thomazzi, S. M.; Paschoalato, A. B.; Poole, S.; Ferreira, S. H.; Cunha, F. Q. Eur. J. Pharmacol. 2000, 387, 111-118.

(22) Medzhitov, R. Nature 2008, 454, 428-435.

(23) Duarte, I. D. G.; Nakamura, M.; Ferreira, S. H. Braz. J. Med. Biol. Res. 1988, 21, 341-343.

(24) Martinez, V.; Thakur, S.; Mogil, J. S.; Taché, Y.; Mayer, E. A. Pain 1999, 81, 163-185.

(25) Pavao-de-Souza, G. F.; Zarpelon, A, C.; Tedeschi, G. C.; Mizokami, S. S.; Sanson, J. S.; Cunha, T. M.; Ferreira, S. H.; Cunha, F. Q.; Casagrande, R.; Verri, W. A., Jr. Pharmacol., Biochem. Behav. 2012, $101,320-328$.

(26) Eddy, N. B.; Leimbach, D. J. Pharmacol. Exp. Ther. 1953, 107, 385-393.

(27) Bhandare, A. M.; Kshirsagar, A. D.; Vyawahare, N. S.; Hadambar, A. A.; Thorve, V. S. Food. Chem. Toxicol. 2010, 48, 3412-3417.

(28) Nemirovsky, A.; Chen, L.; Zelma, V.; Jurna, I. Anesth. Analg. 2001, 93, 197-203.

(29) Quintans-Júnior, L. J.; Melo, M. S.; De Sousa, D. P.; Araújo, A. A. S. J. Orofac. Pain 2010, 24, 305-312.

(30) Amaral, J. F.; Silva, M. I. G.; Neto, M. R. A.; Neto, P. F. T.; Moura, B. A.; Melo, C. T. V.; Araujo, F. L. O.; Sousa, D. P.; Vasconcelos, P. F.; Vasconcelos, S. M.; Sousa, F. C. F. Biol. Pharm. Bull. 2007, 30, 12171220.

(31) McNamara, C. R.; Mandel-Brehm, J.; Bautista, D. M.; Siemens, J.; Deranian, K. L.; Zhao, M.; Hayward, N. J.; Chong, J. A.; Julius, D.; Moran, M. M.; Fanger, C. M. Proc. Natl. Acad. Sci. U.S.A. 2007, 104, $13525-13530$.

(32) Parada, C. A.; Tambeli, C. H.; Cunha, F. Q.; Ferreira, S. H. Neuroscience 2001, 102, 937-944.

(33) Miranda, F. G. G.; Vilar, J. C.; Alves, I. A. N.; Cavalcanti, S. C. H.; Antoniolli, A. R. BMC Pharmacol. 2001, 1, 1-16.

(34) Veras, L. M.; Guimarães, M. A.; Campelo, Y. D.; Vieira, M. M.; Nascimento, C.; Lima, D. F.; Vasconcelos, L.; Nakano, E.; Kuckelhaus, S. S.; Batista, M. C.; Leite, J. R. S. A.; Moraes, J. Curr. Med. Chem. 2012, 19, 2051-2058.

(35) Leite, J. R. S. A.; Miura, L. M. C. V.; Lima, D. F.; Carneiro, S. M. P.; Carvalho, F. A. A.; Moraes, J.; Batista, M. C. S. Br. Patent 2,108, 2011. (36) Casabianca, L. B.; De Dios, A. C. J. Chem. Phys. 2008, 128, 5220152210 .

(37) Voigtländer, H.-W.; Balsam, G.; Engelhardt, M.; Pohl, L. Arch. Pharm. 1978, 311, 927-935.

(38) El Habazi, K.; Aboufatima, R.; Benharref, A.; Zyad, A.; Chait, A.; Dalal, A. J. Ethnopharmacol. 2006, 107, 406-411.
(39) Winter, C. A.; Risley, E. A.; Nuss, G. W. Proc. Soc. Exp. Biol. Med. 1962, 111, 544-547.

(40) Barbosa, A. L.; Pinheiro, C. A.; Oliveira, G. J.; Moraes, M. O.; Ribeiro, R. A.; Vale, M. L.; Souza, M. H. Inflammat. Res. 2009, 58, 235240.

(41) Vasconcelos, D. I. B.; Leite, J. A.; Carneiro, L. T.; Piuvezam, M. R.; Lima, M. R. V.; Morais, L. C. R.; Rumjanek, V. M.; Mascarenhas, S. R. Mediators Inflammat. 2011, 11, 1-12.

(42) Correa, C. R.; Calixto, J. B. Br. J. Pharmacol. 1993, 110, 193-198.

(43) Bradley, P. P.; Christensen, R. D.; Rothstein, G. Blood 1982, 60, 618-622.

(44) Koster, R.; Anderson, M.; Debber, E. J. Fed. Proc. 1959, 18, 412414.

(45) Fasmer, O. B.; Berge, O. G.; Hole, K. Neuropharmacology 1985, 24, 729-734.

(46) Hunskaar, S.; Fasmer, O. B.; Hole, K. J. Neurosci. Methods 1985, $14,69-76$.

(47) Dunham, N. W.; Miya, T. S. J. Am. Pharm. Assoc. 1957, 46, 208 210. 